\title{
POSSIBLE LESSER BLACK-BACKED GULLS AT MOOSE JAW, SASKATCHEWAN
}

\author{
FRANK BRAZIER, 2657 Cameron Street, Regina, Saskatchewan. S4T 2W5
}

On 13 April 1986, about 3:00 p.m., I was alone, driving somewhat slowly (ca $40 \mathrm{kph}$ ) about 10 miles west of Moose Jaw on Highway 1 (Trans-Canada). The traffic was heavy and the weather poor - overcast but the snowfall of the previous night and morning had stopped. There were numerous Ring-billed Gulls along the road.

I noticed a gull (Ring-billed size) standing at the edge of the field across the north ditch. It was probably less than 50 feet away. It was facing me with its head down and at the same time another similar-sized gull flew to it; the first bird then raised its head. The second gull landed for an instant and both took off flying north for a few feet. Both banked sharply to the east for a short distance and then headed south, all the while about 6 feet above the ground. When they banked I had a good view of the entire mantle and wings of both birds, both being solid black from wingtip to wingtip except for the narrow white trailing edges of the wings. I could also see that both bills were yellow. I could not detect any other field marks but the size and solid black mantles and wings with yellow bills were sufficient to identify them as Lesser Black-backed Gulls.

When I reported Saskatchewan's first sight record of a Lesser Black-backed Gull, seen on 28 May 1977 at Regina by Marjie Brazier and me, I noted that there are only five similar black-backed gulls. ${ }^{2}$ We can rule out the Great Black-backed Gull because of its enormous size, also the Southern Black-backed Gull, as it is confined to the Southern Hemisphere, the Slaty-backed Gull, as it is found only in N.E. Asia - Alaskan Coast, the Western Gull as it is confined to the Pacific Coast of North America, but the Lesser Blackbacked Gull is an uncommon, although increasing, regular migrant in eastern North America. Scott now considers it "...casual to uncommon but increasing on Atlantic coast, casual throughout the east." 5 Goodwin for Niagara Falls, Ontario notes they "... have been seen with increasing frequency in recent years." 4 Holshan and Koes report Manitoba's 2nd and 3rd sighting - at Winnipeg, May and June, 1984, respectively. ${ }^{3}$

I mentioned that the Lesser Blackbacked Gull has been a regular Atlantic coast visitor since 1934 and that Canada's first record occurred 5 June, 1968 in the Arctic. ${ }^{2}$ A review of the pages of American Birds reveals that a good number of these gulls pass the winter on the Atlantic seaboard and Gulf of Mexico coast. The Autumn 1984 issue notes at least 65 birds, mostly along the Atlantic coast, on the Gulf coast, but 26 on the Great Lakes including Minnesota's first record. Weir reports 25 birds in Ontario and reasonably conjectures that the two first-winter birds at Long Point supports "... the hypothesis that the species may be nesting in North America."6 Boyle et.al., for the Hudson-Delaware Region, remarks that sightings are now so frequent that some observers do not bother to mention them.'

There were $73+$ birds counted in the winter 1984-1985, 58 + being along the Atlantic Coast. The following spring had 39 reported, 20 of them in Ontario, while the autumn migration issue (1985) once again reports $65+$ birds. Most of these, 
$55+$, were Atlantic coast sightings and 10 were Gulf of Mexico birds.

When we consider the vast flocks of Ring-billed and Herring Gulls that overwinter in the milder Atlantic and Gulf coasts it is likely that they bring with them the occasional Lesser Black-backed Gull when migrating in the spring. If the two I saw were a mated pair perhaps they will settle somewhere in northern North America which has yet to have its first nesting of this species.

'BOYLE, W.J., JR., R.O. PAXTON, and D.A. CUTLER 1985. Hudson-Delaware Region. Am. Birds 39: 150-154.

2BRAZIER, F. 1977. Probable Lesser Blackbacked Gull at Regina. Blue Jay 35:257-258.
${ }^{3}$ GOLLOP, J.B. 1984. Prairie Provinces Region. Am. Birds 38:1031-1033.

${ }^{4}$ GOODWIN, C.E. 1982. A Bird-finding guide to Ontario. University of Toronto Press. p. 63.

${ }^{5}$ SCOTT, S.L. (Ed.) 1983. Field guide to the birds of North America. Nat. Geog. Soc., Washington. 463 pp.

${ }^{6}$ WEIR, R.D. 1985. Ontario Region. Am Birds 38:46-50.

EDITOR'S NOTE: While most birdwatchers do it, identifying a bird, particularly a rarity, based on its geographical distribution cannot be considered an adequate determination. Unfortunately, in this as in many other cases, viewing conditions do not permit observation of the sometimes minute details required to make the identification conclusive.

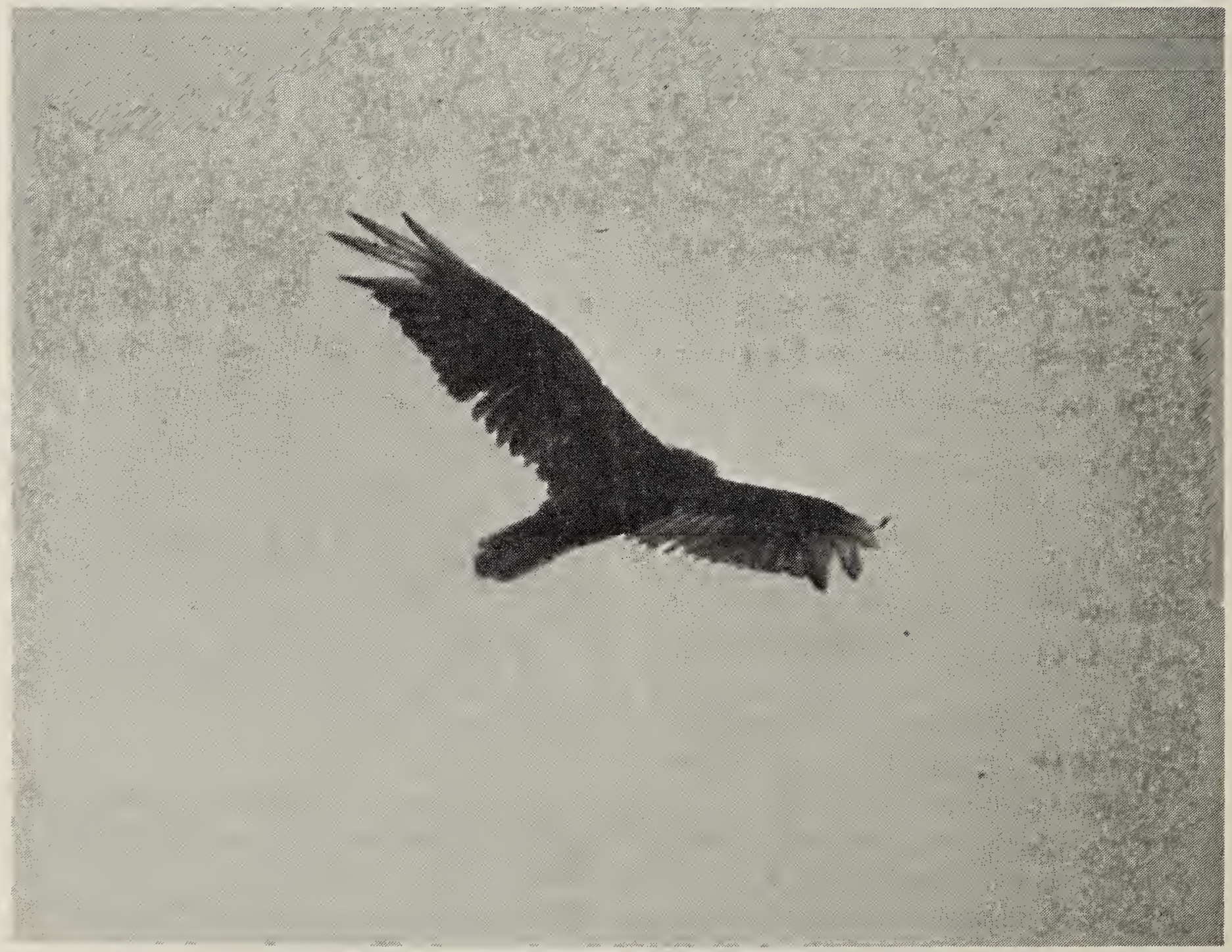

